\title{
Integrative and Disruptive Forces in Contemporary \\ China
}

\author{
Kazuko Mori, \\ Professor, School of Political Science and Economics \\ Waseda University
}

(This paper was delivered to the J apan - India Seminar on Contemporary China at

Dehli University in March 2002.) 


\section{Introduction}

Chinese history has for over a thousand years gone through a cycle of unity followed by a period of defensiveness, then the threat of break-up, followed by disintegration and then unity once again. In the last fifty years of the twentieth century however, integrative forces have been, for the first time, stronger than they have been ever before. This strong integration has been possible because of:

1) nationalism and foreign pressure, 2) as a socialist state the centralisation of politics, economic, culture and other spheres of activity, 3) a homogeneous citizenry (in Chinese renmin or people) and a peoples state that has, as an ideal and an objective, sought to integrate all aspects of life, 4) and finally the existence of a charismatic leader. These have all worked as a cohesive and centripetal force in a country, which, with the largest population in the world and a variety of ethnic minorities, is extremely hard to integrate.

Benidict Anderson writes that "In China Mao Zedong took the example of Stalin and the Emperor and was bold enough to think of building socialism on the base of the Qing Empire. However, Mao tried to forcibly stretch the small cover of nationalism over the vast multi-ethnic, multi-religious, multi-lingual areas under the control of China" [Sekai , September,1993].This attempt was to an extent successful.

This strong integration has also begun to change as the era of Mao has come to a close. The increasing pace of reform and liberalisation towards the end of the Deng Xiaoping era when market liberalisation began to be carried out in earnest was a time when centrifugal forces begin to operate with greater strength. There were a variety of disruptive forces such as the anti-ideological stance that sought to push reform and openness, marketisation and, accompanying that, the appearance of plurality, the increasing desire for autonomy from the centre by the provinces, as well as tension arising from friction between the provinces and the centre, and on occasion the rise of ethnic nationalism in the border regions (the central government initially dealt very severely with them as separatist movements). It must be emphasised that for those who thought of the revitalisation of China the move to separate Taiwan or its independence movement was seen as working to strengthen this trend towards disintegration.

China then from a position of very strong integration began to move to a condition of being defensive but does this mean that there a possibility of this trend leading to the break-up of China? To answer this question I will focus on the following three factors, 1). The Communist Party of China as the bearer of the ideology of unity (centripetal force) and as a unifying political body, 2). The relationship between the centre and the provinces (centrifugal force) and 3). Ethnic nationalism (centrifugal force), to discuss the problem of integration and disruption in the last twenty odd years of reform and liberalisation and in the short term future.

\section{The Ideology of Unification and the CCP}

The first component of the ideology of integration in contemporary China is nationalism. The Chinese Communist Party used nationalism as an ideology of national salvation to motivate the people against the domination of the Western powers. As an ideology of patriotism it could ride out the "containment" of the Cold War. The second factor is the "Chineseification of Marxism-Leninism" or Mao Zedong Thought. Following the Great Leap Forward and the Great Cultural Revolution Marxism-Leninism combined with national salvation and the salvation of the poor to spread to even the remotest village in China.

It was because of this that for thirty years it was possible to protect the country from foreign 
threat without trying to catch up with the developed countries and raise the standard of living of the people. This even influenced the peoples' states of East Asia and even Taiwan. The four modernisations pushed by Deng Xiaoping the leader of the second generation were policies for reforming and opening China and they not only succeeded in quadrupling the GDP in fifteen years but also in making China into "a regional power with a global agenda" (Andrew Nathan). As the WTO membership has shown China is, for the world state system, extremely important for the maintenance of the present world order.

In this period the ideology of integration has changed to one of "an ambiguous mentality" of becoming rich, ideology and patriotism have lost their appeal, even if occasionally the government support pushes a patriotic campaign, in the drive for wealth and profit in the context of marketisation. The exception is Taiwan. The return of Taiwan, a territory "lost to a hundred year modern history of humiliation" is the most important proposition for the Chinese leadership. For instance, in the Presidential elections of 1996 patriotism seemed to catch fire again. Nationalism is still always effective with regard to Taiwan. Therefore, the option of using force for the return of Taiwan has in the last twenty years, with the success of modernisation, disappeared like the cloud and winds; neither do the people want it nor can the leadership exercise that option.

In China where Mao Zedong Thought has certainly lost its effectiveness so has nationalism and today there is no integrative ideology that has a cohesive power. This condition is changing even the CCP the leading actor in Chinese politics. In earlier times the CCP was successful in legitimising its control because it could confront the three main problems in the middle of the twentieth century: repulsing foreign invasion, integration, and uplifting the people from poverty. In the post-Mao period this was converted into the need to modernise and its achievements acted to legitimise the CCP. The success of reforming and opening China were very important in re-legitimising the Party. Now that China has emerged as a regional power in Asia the CCP is forced to search for new achievements that will serve as legitimising principles if it is not to continue as just another ruling party. Even a Chinese theoretician ( Kang Xiaoguang, Academy of Science) says that the period of legitimacy through achievements has ended and now it is necessary to base legitimacy on public fairness or impartiality. ${ }^{1}$

However, the CCP itself has changed considerably during these twenty years. The party continues, as before, to be a symbol of unity, the originator, determiner and executor of policies and provider of leadership at various levels and serves to regulate a variety of interests. The CCP, which used to be the party of the peasantry began to change from the middle of the 1980's and from the nineties it has become a political pressure group of highly educated technocrats. For instance, at the time of the $8^{\text {th }}$ Party Meeting in 1956, 70 per cent of the 10,000,000 party members were peasants and only 14 per cent were workers, that is more than 80 per cent were from the masses. In the year 2000 executives (public servants) professionals, administrative officials and other technocrats form 50.9 per cent of the party membership while workers and peasants are just half of the party. (Peoples Daily June 5,2001). In 1981the educational qualifications of 56 per cent of the 40,000,000 Party members was primary school or below (this included those who were illiterate). In 2000, 50.2 per cent of the total of 64 million members had high school or above qualifications and 80 per cent of the new members who joined the Party were high school graduates or above. (Jinmin nippo, 2001.6.5). In 199790 per cent of the Central Committee Members selected were either university or high school graduates (Jinmin nippo 1999.6.28). This increase in educational qualifications is even more striking in the Assembly for among the members of the Ninth All China Peoples Representative Assembly 70 per cent were

\footnotetext{
${ }^{1}$ Kang Xiaoguang(康暁光) “J ingji zengzhang, shehui gongzheng, Minzhu fazhi yu hefaxing jichu「経 済増長、社会公正、民主法治与合法性基礎」『戦略与管理』(Zhanlue yu

Guanli. Strategy and Management) No.4, 1999.
} 
party members and more than 80 per cent were either university or high school graduates.

Class differentiation has also emerged with economic development and marketisation and a new class of managers of private companies, aside from workers, peasants and management, has also appeared. In August 2001. on the occasion of the memorial meeting of the eightieth anniversary of the establishment of the party, President Jiang Zemin presented the "new theory of the Three Representations". The Party represents the following three things: the development of advanced productive power, the promotion of advanced culture and "benefit for a greater number of the masses". Moreover, he also publicly accepted what had been a long pending question of giving Party membership to owners of private company, writing that it is necessary to "recognise the general plan and regulations of the party,, consciously fight for the general plan, and line of the party, and through long term investigation absorb the superior elements in society that are in consonance with the conditions of the Party members". At present there are 2,800,000 private company owners and 20 per cent are said to be party members. In this manner just from 1980 the Chinese Communist Party has begun to change from a class party to a peoples party, a citizens party.

The disappearance of an integrative ideology may lead to the weakening of the cohesive forces of the unified state of China. However, it is not possible to determine at this point whether the change to a citizens political party would lead to the weakening of the centripetal forces within the party. Even if the party is transformed from a class party to a citizens party as long as the unified party system continues it cannot be said that its cohesive power will suddenly weaken. The integrative power of the unified system as discussed later, in the short and medium term, will affect the three elements of a unified system - the party, state and army.

\section{The Relations between Centre and Provinces}

There has been a great change in centre-provincial relations in the twenty years of reform and opening. If we talk about the 31 provinces, autonomous divisions and directly controlled cities then the problems in centre-provincial relations in the 1990's can be divided into three over-arching categories.

First, reforms have led to decentralisation of authority and for the first time provinces have claimed better terms, put forward demands, and at times even resisted the centre. The powers of the centre, beginning with financial powers, have been whittled away and its earlier authority where "those above have a policy then those below react" has declined and it cannot exercise its authority over the people as effectively.

Second, with reform, opening and marketisation there are times when there is lack of uniformity in the spread of benefits between provinces as well as clashes between provinces. There are growing differences between provinces and at times the freezing of funds by the provincial governments in its extreme form there is a warlord economy at work.

Third, with the above changes in centre-provincial relations brought about by reform and opening, as there is no system or law to regulate the powers and benefits between both parties nothing is fixed and this leads to an arbitrary and unstable situation. There is no guarantee that a strong authority can recover the powers that have been transferred to the provinces and the lower classes.

In the latter half of the nineties, because of these factors many observers understood centre-provincial relations and their future scenario in the following manner:

1. There is no uniformity of benefits, economically or politically, between the centre and the provinces rather there are contradictions, rivalry and clashes. These will increase in the future.

2. There is a possibility that contradictions and clashes will lead to the following situation:

1. Passive or even active resistance by the provinces against the centre can give rise to grave political instability. 
2. If the political, economic and administrative power of the centre continues to decline in this manner then at the national level there may arise economic and political spheres of influence. Consequently the market will be split and the road to a unified market become a very distant dream.

3. There is then, because of these developments, the possibility of political divisions, political instability and the break up of the state. In 1995, in a study commissioned by the US State Department, a certain think tank argued that there was a fifty per

cent chance of China disintegrating because of Taiwan and other problems in the post- Deng Xiaoping era.

What then is the reality? Is China about to break up? It should be noted that Guangtong and Xichuan provinces, which earlier have been areas that resisted the control of the central government, are in the 1990's areas where central control has been strengthened.

The chief characteristics of the situation in contemporary China needs to be seen before approaching the question of the relationship between the centre and the provinces. Socialist China, during the period of the Peoples Party, really had a different political system of control by the people, compared to the advanced Western countries, under which centre-provincial relations were quite restricted in theory, institutionally and in actuality. In China, under a planned economy and the principles of public ownership, the state was both a political institution as well as an economic institution, and it carried out all the functions of collecting, mobilising and distributing capital. The provincial government did exactly the same thing. Centre-provincial relations differed fundamentally with Western patterns in the following areas:

1. In principle the province did not have sovereignty, authority and local autonomy. However, when there was an over concentration of power in the centre, or when there were economic problems, the centre gave a certain degree of authority to the provinces, depending on the need as well as on the situation. In particular financial powers were often distributed.

2. The centre is a multi-functional body. It combines at least three functions, it is a body which has power, it is an economic body and is a political organisation with a variety of jurisdictional authorities in the collection, mobilisation and distribution of capital.

3. The province is also a similar multi-functional body. It combines the three functions of an administrative body, an economic organisation and a political body and at times it acts as a sovereign body. The province also is, in contrast to the centre, a non-state but, in relationship to bodies at a lower level, it represents and appears as the state and in that sense has a dual character. 4. In the shadow of the relationship between the centre and the provinces is the super power of the Party. As in the period of the Great Leap Forward even if, for instance, a wide range of authority and power is transferred to the provinces, the provincial party and as well as the Central Party organs always intervene in the provinces. What is the role of the Party in centre-provincial relations? Is the provincial party a representative of the centre or is it of the provinces? These are issues that pose complex problems.

5. The really important element that regulates centre provincial relations is the authority over personnel that are controlled by the party. The principle that the "party manages the cadre" makes no distinction between centre and provinces and it has been and is even now at the very core of the political system.

These form the external framework that regulates centre-provincial relations and we need to start from these Chinese characteristics and restrictions to observe centre-provincial relations. Prof. Wu Guoguang of Hong Kong Chinese University has noted that centre-provincial relations have gone through five stages since the reform period. ${ }^{2}$

2 Wu Guoguang (呉国光) “Chihoshugi no hatten to seiji tosei, seido tsuiko”「地方主義の発展と政治統 制、制度退行」Amako Satoshi(天児慧編) “Gendai chugoku no kozo hendo 4. Seiji: seiji - chuo to chiho no kozo”『現代中国の構造変動(4)政治：政治 - - 中央と地方の構図』東京大学出版会、(Structural 
Stage I. 1978-1982: The centre and provinces form a political alliance to promote reforms.

Stage II 1982-88: This is the period when the centre decentralises and gives financial powers, industrial management and economic management to the provinces.

Stage III. 1988-1993: In the strategy for economic reforms financial powers become the focus of contradictions, friction and resistance between the centre and the provinces.

Stage IV 1993-1997: In this period there is adjustment in the economic, financial and political relations between the centre and the provinces and central control is re-strengthened.

Stage V 1998-to the present: The period when the centre is re-establishing its control.

In the 1980's decentralisation did take place but the centre was able to reassert its control because for one, local autonomy was only a political arrangement and was not institutionalised and for another, the central network, both financially and in terms of personnel, continued to function.

The percentage of central revenues in the national financial revenues fell by ten points at the end of the 1980's panicking the centre to create, in 1994, a classification of channels for the collection of tax revenues. Tax revenues were divided, according to item and payment, between the centre and the provinces, so that the share of the centre was restored to its original levels.

The centre's control over the party, provincial administration and representatives in the Peoples Assemblies at the provincial level was even more effective in maintaining a system of central control. The Chinese Communist Party had maintained the principle of the "Party controls the cadres" since the 1950's and this more than anything else maintained political stability and control over the party. Since the 1960's the centre directly managed (actually appointed) 13,000 cadre throughout China but in the 1980's this authority was largely given to the provinces so that this number was reduced to 4,200. The centre, however, continued to exercise great power by controlling over fifty important posts at the provincial level. In 1990, according to the "List of Offices Managed by the Centre of the Chinese Communist

Party" the centre made direct appointments to the following posts: ${ }^{3}$

Secretary, Provincial Communist Party Committee, Deputy Secretary, Standing Committee Member, Chairman and Deputy-Chairman of the Organisation Committee.

Director and Deputy Director of Provincial Communist Party Advisory Committee.

Secretary and Vice-Secretary of the Provincial Communist Party Regulatory Committee

Its not only these appointments but from the end of the 1990's the centre made many changes in the appointments of the cadre bringing about a generational change in personnel. The Secretaries of the Provincial Party Committees and Provincial Governors from thirty provinces were moved between the end of 1997 and August 1998, according to a survey. This was a clever measure to weaken the provincial identity of the cadre as well as to restore the centre's authority over appointments and dismissals.

In the beginning of the1990's the provinces were very active and conditions were not conducive to their falling in line with the views of the centre. China saw, at this time a very intense debate on the question of "strong centre and state" "or strong province and society".

The conservative social scientist Hu Angang, and others like him, supported the "strong centre" argument. Hu stressed the need for a system of dividing taxes to stabilise central finances and putting an end to the welcome given to measures to build special economic zones and emphasised the need to resolve growing differences. In his statement "Research Report on the Capacity of the State" he makes the following points:

Change in Contemporary China Vol.4 Politics: The Structure of Central and Local Power), University of Tokyo Press, 2000.

3 原典は、"Chugoku rodo jinjibu hen”中国労働人事部編 (China Labour Personnel department Ed.) “J inji kosaku bunken senhen” 『人事工作文件選編』(Select References to Personnel Policies) 13 Vols. 
1. The reduction of the financial resources of the state are neither desirable for stability nor for the marketisation of the economy.

2. Decentralisation is being practiced world wide but actually in the developed world the concentration of finances with the centre is increasing.

3. In a large populous country like China reforms and marketisation have to be carried out under the direction of the central government.

4. To manage centre-provincial relations well a mechanism for adjusting profits, demarcating authority relations, and institutionalisation are essential.

5. The desirable system of centre-provincial relations in China would be a mixture of centralisation and decentralisation. 4

Scholars such as Zhang Shuguang, a Chinese scholar now resident in the United States, have, however, been severely critical of such views arguing that a "strong government, strong centre" leads to the expansion of the powers of the State and infringes the economic freedom of the individual. They argue that the reduction of State power is really the best policy for maketisation. ${ }^{5}$

In effect, the reality of China is along the lines emphasised by Hu Angang. The reason that provincialism has not become a strong factor in changing the politics of contemporary China is because one, the central government will absolutely never hand the right over personnel to the provinces, and two, it will never allow for a system of decentralisation. So provinces cannot ally to resist the centre. The right over personnel functions as the core of the centres "divide and rule" policy.

If the above points are considered then its impossible to think of a scenario where a policy of decentralisation or regionalism will weaken the unity of China and lead to the danger of a break-up, as long as economic growth and the system of the three elements of party-state-army continues to function.

\section{Movements for Ethnic Nationalism}

What about tension over ethnicity or religion, which have been noted as causes for the disintegration of China. ${ }^{6}$

A nation is usually defined basically as a peoples state with the majority of its people belonging to the same culture. Also as far as possible, in a nation-state the system political system, rules, economic power and the peoples' right to self-determination are elements that bind the people into a group. An ethnic group is seen as a group that seeks recognition or equality and protection within a nation state even more than the right to self-determination. Therefore, occasionally there are divisions or independence movements because of the existence of a small ethnic group. Looking at the situation since the end of the twentieth century we can see a blurring of boundaries between the world of the nation and of the ethnic group. Wherever ethnic disputes occur it is

4 Wang Shaoguang (王紹光) · Hu Angang (胡鞍鋼) “Zhongguo guojia nengli baogao”『中国国家能力報 告』Hong Kong, 1994.

5 Zhang Shuguang (張曙光) “Guojia nengli yu zhidu biange he shehui yunxing”「国家能力与制度变革 和社会転型」(State Power, Institutional Change and Social Transition) Dong Pudai (董輔乃) “Jiquan yu fenquan -- zhongyang difang guanxi de goujian”『集権与分権 - - 中央地方関係的構建』 (Centralization and Decentralization--Construction of Centre-Local Relations) 1996.

${ }^{6}$ I deal with this problem in detail in Mori (毛里) “Shuen kara no chugoku” 『周縁からの中国 - - 民族 問題と国家』(Ethno-Nationalism in Contemporary China)、Tokyo University Press, 1998 and Mori, “Chuka sekai no Identity no henyoku to saijuzo”「中華世界のアイデンティティの変容と再鋳造」in Mori (Ed.) “Gendai chugoku no kozo hendo 7. Chuka sekai - Identity no saihen” 『現代中国の構造変 動(7)中華世界 - - アイデンティティの再編』Structural Change in Contemporary China, Vol.7, Transfiguration of China Identity), Tokyo University Press, 200, etc. 
because these groups face certain conditions and, if certain conditions exist then, there is always a potential possibility for division or of independence.

In the case of China it must also be pointed out that there are large numbers of peoples in the frontier regions and these form political communities (particularly the Tibetans and Uighurs) that have a different culture, historical experience and memory.

The central government is hypersensitive to the ethnic groups that are only seeking diversity or political and economic benefits and it is this hypersensitivity that in a contrary way transforms these ethnic and religious contradictions into disputes, politicises them and stimulates a tendency towards division and independence.

In China ethnic disputes in Tibet and Xinjiang increased in the 1980's and 1990's. There were demonstrations demanding an independent Tibet and raising the slogan of "Get Out Han Chinese". Monks in Lhasa led these demonstrations in September and October 1987. March 1989, the thirtieth anniversary of the Tibetan Uprising, was marked by some of the biggest clashes. On this occasion the Tibetan monks and priestesses also held up the flag for Tibetan Independence. Over a hundred people were killed, according to Western reports. Martial law was enforced in Lhasa for the next year.

There was a clear connection between this movement and the activities of the 14th Dalai Lama outside Tibet. In September 1987 the Dalai Lama testified to the Human Rights Committee of the House of Representatives, in the United States. While asserting that Tibet used to be an independent country, he demanded making all of Tibet a zone of peace, stopping the policy of bringing in Han immigrants, respect for fundamental human rights and freedom, restoration of the natural environment of Tibet and that Tibet and China should discuss the future of Tibet (Five Point Proposal). In June 1988 in a speech to the European Parliament he proposed that the Peoples Republic of China and Tibet together establish a democratic and self governing region but restricted himself to stating that the Tibet region in China be given "a high degree of autonomy".

At the end of the 1980's attempts were made to have indirect contacts between the central government and the Tibetan government in exile but they ended with the Tiananmen Incident. It is said that there is still a small channel of communication between the two. It must be noted also that there are no reports of riots in Lhasa nowadays.

The condition in Xinjiang, where there is a Muslim majority, is even more sensitive then Tibet. This is because, with the collapse of the Soviet Union, the newly independent states of Central Asia are contiguous to this area and of course also because of the intensification of Muslim fundamentalism around the world. In April 1990 an uprising occurred at the village of Baran, near Kashgar. It was an anti-socilaist movement that demanded the expulsion of Han Chinese from Xinjiang and it established the Eastern Turkestan Islamic Party and, according to the authorities, initiated an armed struggle. It is said that more than 20 people died in the uprising. In this connection it needs to be noted that in Kashgar, an oasis in south Xinjiang, eight per cent of the population is Uighur Muslim.

In February 1997 in the Inin region a destructive movement by minority ethnic separationists led to clashes. It is said that more than seventy people died in the clash between Han Chinese and Uighur. Inin is just eight $\mathrm{km}$. from Khazakistan and is the region where in 1940 the flag of independence flew for one year.

The central governments policy towards ethnic and religious disputes is: 1).Political exclusion and criminal penalties for ethnic separatists, 2). Strict control over religious activities, 3). Close cooperative action with the neighbouring Islamic

countries to meet the challenge. Together with these measures economic development in crucial areas was promoted in the frontier regions to reduce widening economic disparities and prevent disputes.

The terrorist action on September 11, 2001 that simultaneously targeted New York and Washington brought about changes in the response of the Chinese government to the problem of 
Islam. China began to develop a multilateral mechanism with the Central Asia Republics against Islamic fundamentalism and separatism. This mechanism was the Shanghai Co-operation Organisation formed in June 2001 by Kazakhistan, Kirighistan, Tajikistan, Uzbekistan and the Russian Republics. This organisation was formed by these countries to co-operate on economic and energy issues and build confidence and work together to deal with Islamic fundamentalism and terrorist activities. In the declaration it was agreed that the Shangahi Co-operation Organisation would establish an anti-terrorist centre in Bishkek, Uzbekistan and form an alliance (this was established between Uzbekistan and China) to meet the attacks of terrorism, separatism and extremism. This regional co-operation seems to be proceeding according to plan even after the September 11 incident.

The Chinese response to the Islamic fundamentalist organisations in Xinjiang needs to be noted. On 14 November Zhu Bangzao, the Chinese spokesman while stressing that terrorism is an "international pollutant" said that since 1992 in Xinjiang there have been sporadic destructive terrorist incidents carried out by the "Eastern Turkestan Peoples Islamic Party" and that terrorist organisations in Xinjiang have been supplied arms and money by the extremist organisations of Osama bin Laden and the Taliban and some have even received military training in Afghanistan. ${ }^{7}$

It understandable that China is sensitive to the activities of Islamic fundamentalist extremist organisations but one must be sceptical about any assertion that this is a critical situation or that these organisations have spread all over Xinjiang.

In China after the 1980's ethnic and religious disputes can be categorised in the following manner:

1. Economic disputes ----reaction to poverty or economic disparities, as well as to the one sided exploitation of natural resources or to its plunder.

2. Cultural disputes ---reactions to ethnic discrimination, limit on children, imposition of a particular language, introduction of practices that do not fit with the ethnic culture and customs.

3. Political disputes ---reaction to the framework of local autonomy or the high-handedness of the cadre, the immigration of Han Chinese, nuclear experiments or the disposal of nuclear waste products.

4. Economic, cultural and religious clashes within ethnic groups.

5. Groups that desire self-determination and separation.

No matter what the Chinese government says the disputes in the 1980's and 1990's have not been separatist or independence movements but rather of types 1-4. The fast pace of marketisation has, on the one hand, widened economic disparities and increased type 1 disputes ${ }^{8}$ and, on the

7 www.people.com.cn. 2001.11.16 (http:// www.peopledaily.com.cn/GB/ shizheng)
8 The economic and cultural differences between the eastern, central and western areas of China have
clearly increased in the last twenty years. In 1980 the per capita GDP ratio was $1.5: 1.1$ but in 1998 it
was 2.5:1.5. Please refer to Chart I. The differences in education and information were particularly
serious. The number of illiterates in the 15 and above population group per 1000 is shown in Table I.

Table I. Illiterates per 1000 Persons (above 15 yrs old.)

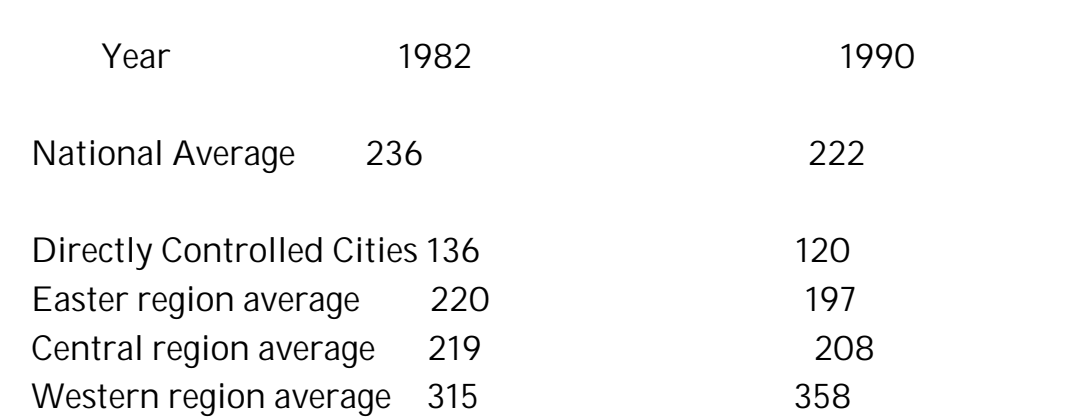


other hand, has created an unease that minority culture and customs will be destroyed leading to an increase in type 2 disputes. The type of marketisation that is engulfing the world is working in the same manner as globalisation, that is, uniting the world but increasing the problem of poverty. In Tibet more than a movement for division it is shifting to a movement for human rights and democracy. Strictly speaking the Tibetan uprising in 1959 has been the one unique example of a serious movement for division or self-determination that sought the disintegration of the state.

There will be disputes in China in the future that involve ethnicity and religion but it will be an over-reaction if the central government seeks to suppress them all as movements that are divisive or demanding independence. However, the September 11 incident has given the central government a good excuse. It is necessary to point out that if the central government over reacts to movements that are in no way divisive movements or demands then there is a danger that they will be driven in this direction.

\section{Conclusion}

The reason that Chinese politics continues to remain stable, despite social changes that have seen the spread of benefits leading to a decline in the power of ideology, the changing composition of the Communist Party and the intensification of

marketisation, is because the core of this unity, the three elements of a unified system the party, state and army, have not been fundamentally affected. There are certainly many factors that lead China towards disintegration. Therefore, the relationship of the party which, is at the core of the triangle continues to be of importance. Earlier in the period 1910-1930 military power and regional authority came together to form the warlord system but the army, as the people's army, is at the base of the strong control exercised by the Party. The National Defence Law of 1997 established, for the first time, the Party's control over the army in law. In the former Soviet Union the separation of the Party, State and Army began in the 1970's and by the end, because the army was completely independent from the control of the Party, in 1991, it took a wrong step. It must be said, however that there is little likelihood that China will follow the path of the former Soviet Union.

As noted earlier, because of the transformation of the Party to a people's party, as well as the diversification of society, China is changing from a hard sovereign state to a soft sovereign state. Will this stability continue in the future?

Foreign intervention exploited and exacerbated peasant uprisings, internal corruption and the break-up of regions during the Qing and Republican rule. If, using this analogy, one thinks of the future of the system, then, as there is no foreign

intervention that could strengthen the forces of disruption then only the other two dangers remain: a peasant uprising caused by a crisis in the villages can threaten the system or the danger posed by internal corruption.

[出典 : Lin Yanping (林燕平), “Chugoku no chiiki kan shotoku kakusa”『中国の地域間所得 格差』"Nihon keizai hyoronsha”, 2001, pp.185-6、 


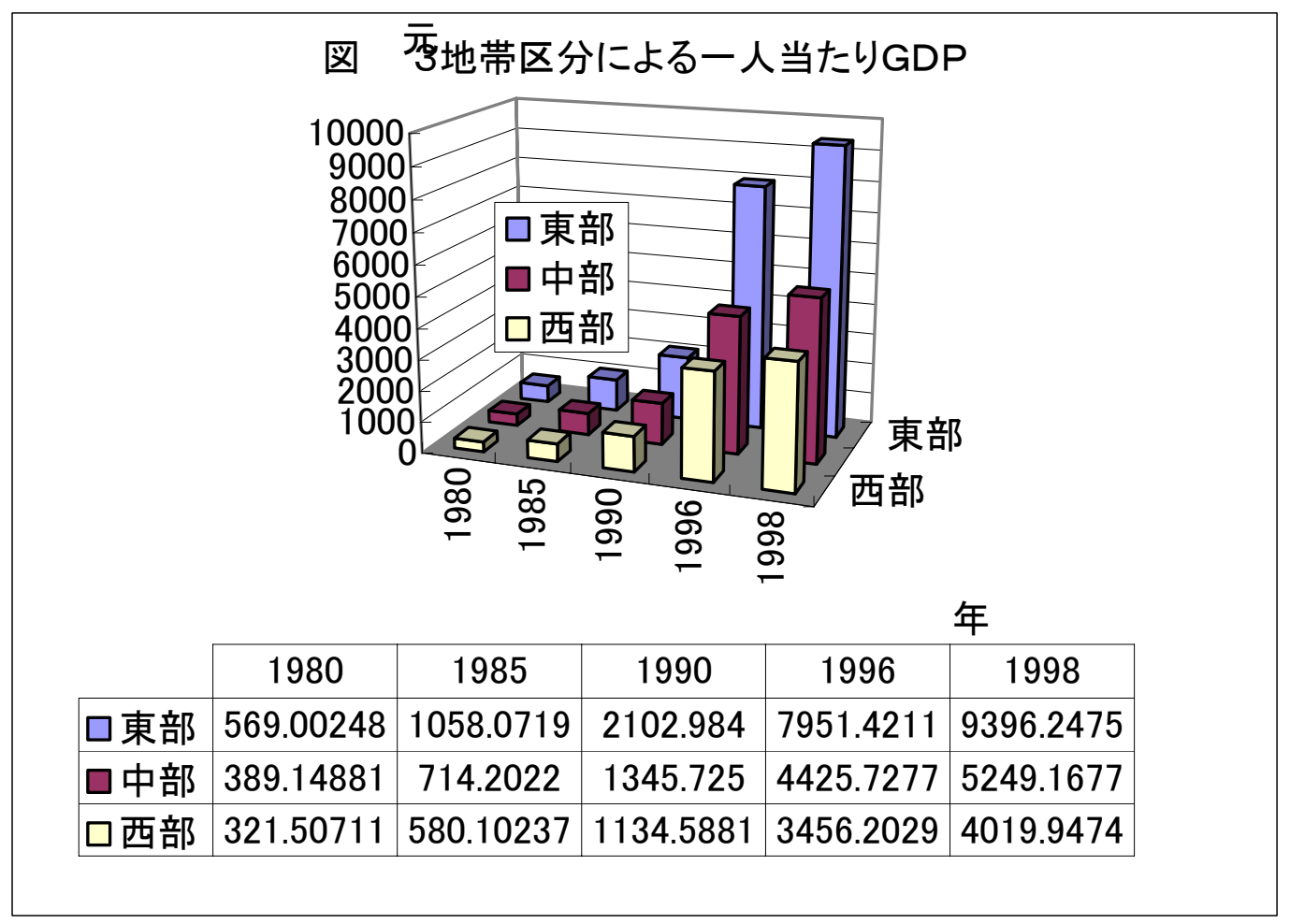

